\title{
Shoot and Root Responses of Trifolium vesiculosum to Boron Fertilization in an Acidic Brazilian Soil
}

\author{
Nerilde Favaretto ${ }^{1 *}$, Antônio Carlos Vargas Motta ${ }^{1}$, Cristina Barcik ${ }^{1}$, Sebastião Brasil \\ Campos Lustosa ${ }^{2}$ and Jucinei José Comin ${ }^{3}$ \\ ${ }^{I}$ Departamento de Solos e Engenharia Agrícola; Universidade Federal do Paraná; Rua dos Funcionários, 1540; \\ nfavaretto@ufpr.br; mottaacv@ufpr.br; 80035-050; Curitiba - PR - Brasil. ${ }^{2}$ Centro de Ciências Agrárias e \\ Ambientais, Universidade Estadual do Centro-Oeste; Campus de Guarapuava; Rua Presidente Zacarias, 875; C.P. \\ 3010; 85015-430; Guarapuava - PR - Brasil. ${ }^{3}$ Departamento de Engenharia Rural; Universidade Federal de Santa \\ Catarina; Bairro Trindade; 88040-970; Florianópolis - SC - Brasil
}

\begin{abstract}
To analyze the influence of boron fertilization on shoot and root growth of Trifolium vesiculosum (arrowleaf clover), an acid soil profile (60 cm depth with $67 \%$ Al saturation) was recreated in a column (three layers of $20 \mathrm{~cm}$ each). Lime and fertilizer ( $P$ and $K)$ were incorporated into the top $20 \mathrm{~cm}$. The treatments consisted of six boron rates where boric acid was mixed throughout the profile. Addition of boron to soil with low $\mathrm{pH}$ and high Al increased the root and shoot growth, independent of the rate applied. Boron inhibited Al toxicity, but no effect was observed in the root length when Al was not present in the soil. It was also observed that there was more root growth below the plow layer $(0-20 \mathrm{~cm}$,) suggesting better root distribution in the soil profile which could be important for the plant growth, especially under drought conditions.
\end{abstract}

Key words: Root and shoot growth, boron, aluminum, acidic soil

\section{INTRODUCTION}

The development of root system involves complex belowground interactions. The chemical conditions of the soils have a great influence on the root growth. It is well known that high levels of aluminum ( $\mathrm{Al}$ ) inhibits the root growth. In agriculture, especially in the tropics, aluminum toxicity is one of the main factors that limits crop production in acid soils. Soil acidity and consequently $\mathrm{Al}$ toxicity in the upper soil layers can be easily corrected by liming, however, due to slow mobility of lime material, surface application without some degree of mixing are not effective in correcting subsoil acidity. Neutralization of subsoil acidity through deep incorporation is possible, but it increases cost and in some situations, no beneficial effects on crop production are observed (Tisdale et al., 1993).

Besides Al toxicity, boron (B) deficiency is another important factor that inhibits the root growth (Marschner, 1995; Castro et al., 2003). Studies have shown that boron fertilization can decrease the effect of Al toxicity (LeNoble et al., 1996a, 1996b; Lukaszewski and Blevins, 1996). According to LeNoble et al. (1996a), it is possible that $\mathrm{Al}$ inhibits root growth by inducing boron deficiency and that the boron requirement for optimal root growth under acidic and high $\mathrm{Al}$ conditions may be higher than the requirement

\footnotetext{
* Author for correspondence
} 
under low $\mathrm{Al}$ levels. In soil, boron is considered a mobile element, easily reaching subsoil layers. Thus, leaching of surface applied boron could increase the boron level in the subsoil, thereby increasing the depth of the root growth (Smith et al., 1993; LeNoble et al., 1996b). However, the narrow concentration range between boron deficiency and toxicity requires special care in boron fertilization (Gupta et al., 1985; Marschner, 1995; Grassi Filho et al., 2004). Among the sources of boron in soil, organic matter plays an important role, thus, plants growing in sandy soils tend to develop boron deficiencies because of very low organic reserves (Gupta et al., 1985; Luchese et al., 1994).

Plants have different requirements and usually dicotyledons are more exigent than monocotyledons. In plants, boron is classified as an immobile element, consequently symptoms of deficiency in the shoots are noticeable on the youngest leaves, and the internodes are shorter giving the plants a bushy or rosette appearance (Gupta et al., 1985; Marschner, 1995).

In southern Brazil, many forage species have been introduced, including Trifolium vesiculosum, Savi (arrowleaf clover), a winter annual legume. For good development the soil $\mathrm{pH}$ should be between 5 and 6 and boron may be needed in sandy soils to enhance the root growth (Hoveland and Evans, 1995). According to Gupta et al. (1985), the optimum hot-water extractable boron level in soil for clover growth was generally greater than 0.5 $\mathrm{mg} \mathrm{kg}^{-1}$.

The overall objective of the present study was to determine if boron applied at different rates could reduce subsoil Al toxicity in Trifolium vesiculosum crop. The hypothesis was that boron could decrease the effect of $\mathrm{Al}$ toxicity on the root growth mainly.

\section{MATERIALS AND METHODS}

This experiment had six treatments (boron rates), arranged in a completely randomized design with six replicates and was conducted at the greenhouse complex of the Soil Department of the Federal University of Paraná State, Curitiba, Brazil. The soil profile was recreated in white plastic columns (20 cm diameter, $63 \mathrm{~cm}$ long) with three layers of soil $(0-20,20-40$ and $40-60 \mathrm{~cm})$ here referred as the A, B, and C layers, respectively. The soil used was removed (also in three layers) from a grassland field in Ponta Grossa, Paraná. The soil was a "Cambissolo álico" with medium texture, high $\mathrm{Al}$ content, and low $\mathrm{pH}$, organic matter and nutrients. The chemical and physical properties of each layer are presented in Tables 1 and 2.

$\underline{\text { Table } 1 \text { - Physical properties and concentrations of micronutrients of grassland soil sampled at three depths. }}$

\begin{tabular}{|c|c|c|c|c|c|c|c|c|c|}
\hline \multirow{2}{*}{$\begin{array}{c}\text { Layer } \\
\mathrm{cm}\end{array}$} & Sand & Silt & Clay & \multirow{2}{*}{$\begin{array}{c}\text { Bulk density } \\
\mathrm{kg} \mathrm{dm}^{-3}\end{array}$} & $\mathrm{Cu}$ & $\mathrm{Fe}$ & $\mathrm{Mn}$ & \multirow[t]{2}{*}{$\mathrm{Zn}$} & \multirow{2}{*}{$\begin{array}{c}\mathrm{B} \\
\mathrm{mg} \mathrm{dm}^{-3} \\
\end{array}$} \\
\hline & &. $\mathrm{g} \mathrm{kg}^{-1}$ & & & \multicolumn{3}{|c|}{$\ldots \mathrm{mg} \mathrm{kg}^{-1}$} & & \\
\hline A $(0-20)$ & 700 & 80 & 220 & 1.35 & 4.4 & 67.8 & 14.0 & 2.9 & 0.23 \\
\hline B $(20-40)$ & 660 & 120 & 220 & 1.35 & 0.6 & 53.2 & 8.0 & 0.3 & 0.22 \\
\hline $\mathrm{C}(40-60)$ & 720 & 80 & 200 & 1.45 & 0.4 & 35.1 & 6.4 & 0.4 & 0.19 \\
\hline
\end{tabular}

Table 2 - Chemical properties of grassland soil sampled at three depths.

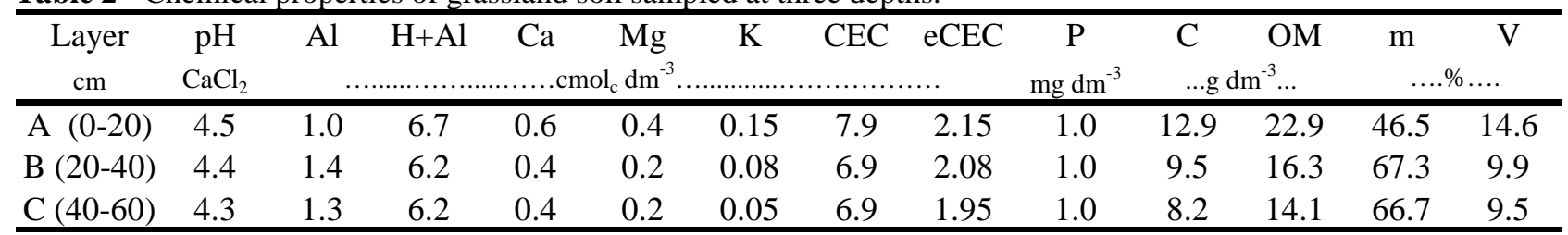

$\mathrm{CEC}=$ Cation exchange capacity at $\mathrm{pH} 7$; $\mathrm{eCEC}=$ Cation exchange at native $\mathrm{pH} ; \mathrm{V}=$ Base saturation (sum of base/CEC); $\mathrm{m}=$ Aluminum saturation $(\mathrm{Al} / \mathrm{eCEC}), \mathrm{OM}=$ Organic matter $\left(\mathrm{C}^{*} 1.72\right)$ 
Soil particle and bulk density were determined by the hydrometer and cylinder methods, respectively, according to EMBRAPA (1997). The $\mathrm{pH}$ was determined in $\mathrm{CaCl}_{2} 0.01 \mathrm{M} ; \mathrm{H}+\mathrm{Al}$ via SMP solution; $\mathrm{Ca}, \mathrm{Mg}$ and $\mathrm{Al}$ extracted by $\mathrm{KCl} 1 \mathrm{~N}$; $\mathrm{P}$ and $\mathrm{K}$ via Mehlich I; total organic $\mathrm{C}$ by colorimetry (Pavan et al., 1992); $\mathrm{Fe}, \mathrm{Mn}, \mathrm{Cu}$, and $\mathrm{Zn}$ by $\mathrm{HCl} 0.1 \mathrm{~N}$ (Hildebrand, 1977); and B by $\mathrm{BaCl}_{2}$ using the microwave technique of Abreu et al. (1994).

The upper soil layer $(0-20 \mathrm{~cm})$ was limed $(4.3$ $\mathrm{Mg} \mathrm{ha}{ }^{-1}$ ) according to the base saturation recommendation (IAC, 1996) and fertilized with 320 and $140 \mathrm{~kg} \mathrm{ha}^{-1}$ of $\mathrm{P}_{2} \mathrm{O}_{5}$ (phosphate monocalcium) and $\mathrm{K}_{2} \mathrm{O}$ (potassium sulfate and chlorite), respectively. Since this experiment was conducted in the pots, the $\mathrm{P}$ and $\mathrm{K}$ addition was double the value recommended for the field clover by Comissão de Fertilidade do SoloRS/SC (1994). Liming and fertilization were conducted one month before and at the day of planting, respectively. The chemical condition of soil in layer $\mathrm{A}(0-20 \mathrm{~cm})$ at planting was the following: $\mathrm{pH} \mathrm{CaCl} 2$ (5); $\mathrm{Al}^{3+}, \mathrm{H}^{+}+\mathrm{Al}^{3+}, \mathrm{Ca}^{2+}$, $\mathrm{Mg}^{2+}, \mathrm{K}^{+}$, and CEC $(0,4,2.1,1.6,0.24$ and 7.9 $\mathrm{cmol}_{\mathrm{c}} \mathrm{dm}^{-3}$, respectively); Al saturation and base saturation ( 0 and $50 \%$ respectively). The second and third layers did not receive lime and $\mathrm{P}$ and $\mathrm{K}$ fertilizer. All three layers received the same amount of B (boric acid) according to the respective treatments $(0,0.25,0.5,0.75,1$ and 2 $\mathrm{kg} \mathrm{ha}^{-1}$ of B).

After the fertilization, each pot received 10 arrowleaf clover (Trifolium vesiculosum) seeds inoculated with rhyzobium. After seedling establishment (30 days), pots were thinned to four plants per pot. Plants were watered periodically with deionized water. The experiment was conducted until flowering (4.5 months). Aboveground biomass was sampled, cleaned with deionized water and dried for the determination of weight and nutrient concentration. Boron concentration was determined on sieved $(2 \mathrm{~mm})$ biomass samples for all the experimental units via dry digestion according to Hildebrand (1977).

Root samples were collected from each layer and cleaned with water using a set of sieves with screen openings of 2 and $0.2 \mathrm{~mm}$. The separation of clover roots from the organic debris was done by hand using tweezers. Afterwards, the roots were stored in plastic bags containing 50\% ethanol and placed in a freezer $\left(0{ }^{\circ} \mathrm{C}\right)$. The variables measured were root dry weight, length and medium ratio. The root mass was determined after oven drying the samples at $60{ }^{\circ} \mathrm{C}$ until constant weight was attained. Root length was determined according to Tennant (1975) using the following equation: $\mathrm{C}=\mathrm{N}^{*} \mathrm{fc}$, where: $\mathrm{C}$ was the length $(\mathrm{cm}), \mathrm{N}$ was the number of intersections and fc was a correction factor. The screen used for counting the root intersections had $1 \mathrm{~cm}^{2}$ square grids with an $\mathrm{fc}$ value of 0.7857 . The total length in each layer was calculated from a $0.5 \mathrm{~g}$ subsample of wet mass. The medium ratio was calculated according to Shenk and Barker (1978) using the following equation: $r=\left(\mathrm{mf} /\left(\mathrm{c}^{*} \pi\right)\right)^{0.5}$, where: $\mathrm{r}$ was the medium ratio, $\mathrm{mf}$ was the wet weight and $\pi$ was a constant. During the root sampling, soil samples were collected from each layer to determine boron concentration.

Analyses of variance and mean comparison were made using SAS software. Soil and root variables were analyzed using a split plot model where rate of boron correspond to the whole plot and layer to the subplot; other variables were analyzed as one factor in a complete randomized model. Preliminary statistical analyses indicated that some variables had to be transformed in order to achieve the requisites for an analysis of variance. A regression between the log (standard deviation) and $\log$ (mean) was performed for each variable to define which transformation should be used (Box et al., 1978). When necessary, the data were transformed, but presented in their original form.

\section{RESULTS AND DISCUSSION}

\section{Plant growth}

The shoot dry weight increased up to $130 \%$ with boron fertilization. The smallest mean $(5.03 \mathrm{~g}$, treatment without boron) was significantly different from means of all boron applied rates (Fig. 1). In agreement with these results, Haby et al. (1993) and Smith et al. (1993) reported a significant increase in the clover shoot growth when boron was applied to an acid sandy soil from Texas. The maximum increase $(11.52 \mathrm{~g})$ was obtained from $0.5 \mathrm{~kg} \mathrm{ha}^{-1}$ application of $\mathrm{B}$, however, no significant differences were 
observed among boron rates, except on $0.75 \mathrm{~kg}$ $\mathrm{ha}^{-1}$ of B (Fig. 1). Since all the treatments received lime in the upper soil layer and that they had high Al levels in the subsoil, results indicated that boron could reduce the effects of Al on aerial growth. LeNoble et al. (1996b) observed that high $\mathrm{Al}$ in the subsoil inhibited shoot growth of alfalfa, but they did not report significant differences in treatments with supplemental boron.

As expected, the level of boron in plant tissue increased linearly with boron fertilization (Fig.1). The maximum value $\left(50 \mathrm{mg} \mathrm{kg}^{-1}\right)$ was for the pots treated with $2 \mathrm{~kg} \mathrm{ha}^{-1}$ of B and the smallest $\left(35 \mathrm{mg} \mathrm{kg}^{-1}\right.$ ) for the controls (no boron applied).

According to Gupta et al. (1985), dicots (e.g., clover), required more boron than monocots. For white clover in association with ryegrass, the critical level of boron in tissue was $25-35 \mathrm{mg} \mathrm{kg}^{-1}$
(Dunlop and Hart, 1987), and for red clover, concentrations less than $20 \mathrm{mg} \mathrm{kg}^{-1}$ were related to boron deficiency symptoms (Gupta et al., 1985). Deficiencies in the field occurred when boron levels in the plant was less than $15 \mathrm{mg} \mathrm{kg}^{-1}$ (dry weight basis) while boron concentration between 20 and $200 \mathrm{mg} \mathrm{kg}^{-1}$ were adequate for the growth. Boron toxicity under field conditions generally occurred when plant concentrations exceed $200 \mathrm{mg} \mathrm{kg}^{-1}$. However, these were only general guidelines, and plants responded differently depending on many factors, including species and soil conditions (Gupta et al., 1985; Marschner, 1995). In this experiment, symptoms of deficiency and toxicity were seen in both the control and the $2 \mathrm{~kg} \mathrm{ha}^{-1}$ of $\mathrm{B}$ treatments. However, the levels of boron in the plant tissue ( 35 to $50 \mathrm{mg} \mathrm{kg}^{-1}$ ) would have been considered adequate.

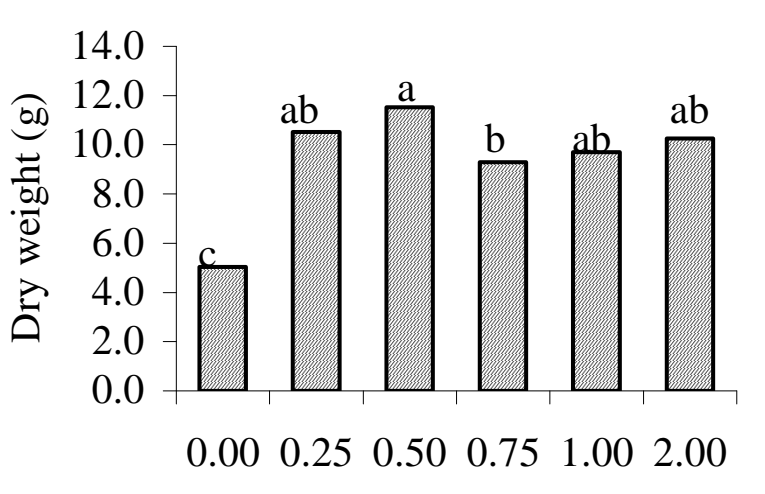

Rate of soil boron $\left(\mathrm{kg} \mathrm{ha}^{-1}\right)$

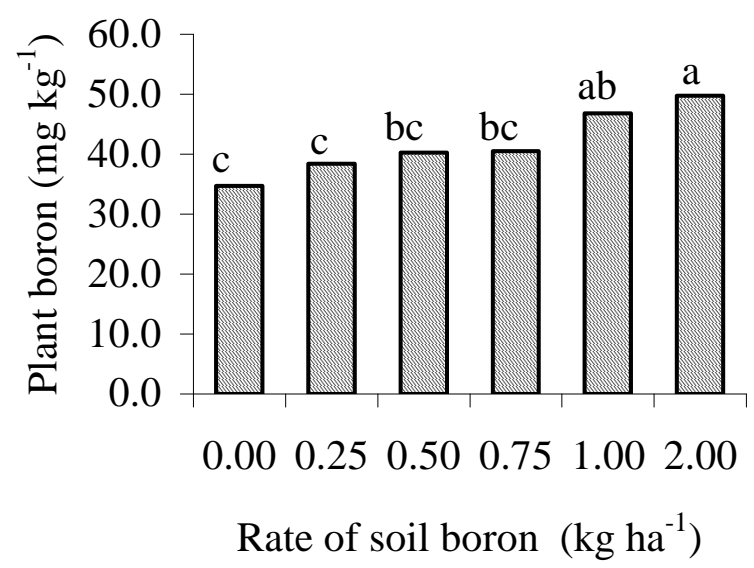

Figure 1 - Shoot dry weight $\left(\mathrm{g} \mathrm{pot}^{-1}\right)$ and plant boron level $\left(\mathrm{mg} \mathrm{kg}^{-1}\right)$ as affected by boron fertilization in a profile with high $\mathrm{Al}$ in the subsoil. Means followed by the same letter within each variable are not significantly different by Tukey's test at $5 \%$.

\section{Root growth}

\section{Root dry weight}

Root dry weight in each layer was significantly higher in the treatments with applied boron compared to the control with no B (Fig. 2), indicating that boron promoted root growth (Smith et al., 1993; Lukaszewski and Blevins, 1996). However, no statistical difference was observed among the rates of boron applied. LeNoble et al. (1996b) observed higher dry weight for treatments with boron applied throughout a subsoil having a high $\mathrm{Al}$ level, but they reported statistical differences only at the $90-120 \mathrm{~cm}$ depth. The soil aluminum status could explain the difference since LeNoble et al. (1996b) used soil with lower Al saturation compared with that used in this experiment.

Increased root dry weights of 74-88, 100-198, and $498-693 \%$ were observed for the respective first, second, and third layers where boron was applied compared to the control. Thus, enhancement of root growth due to boron application occurred throughout the whole soil profile. Large increases in root dry matter with 
boron application was also reported by LeNoble et al. (1996b) who found a 300\% increase at the 90-120 cm depth. Changes in root dry weight at the $0-20 \mathrm{~cm}$ depth was not expected due to soil acidity correction, suggesting a natural lack of B.

Measurement of dry weight by the layer provided information about root behavior with depth. Results showed that the roots grew mainly in the A layer, decreasing gradually with depth. The dry weight in layers A, B, and C was
2.80, 0.40 and $0.33 \mathrm{~g}$, respectively. Considering total root growth $(3.53 \mathrm{~g})$ independent of the applied boron, layers A, B and C constitute 79.3, 11.3 and $9.4 \%$ of the total, respectively. The contribution of each layer within each rate of boron applied is shown in Fig. 3. Boron application resulted in better root distribution since only $12 \%$ of root dry matter was found in the $\mathrm{B}$ and $\mathrm{C}$ layers without boron as compared to 19- $25 \%$ with boron.

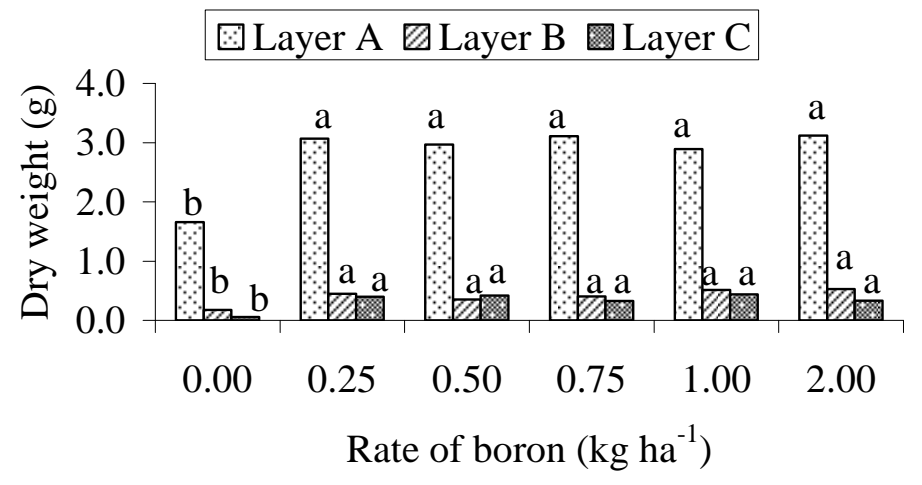

Figure 2 - Root dry weight (g) as affected by boron fertilization in a profile with high $\mathrm{Al}$ in the subsoil. Means followed by the same letter within the each layer are not significantly different by Tukey's test at $5 \%$. Layer A $(0-20 \mathrm{~cm}), \mathrm{B}(20-40 \mathrm{~cm})$ and C $(40-60 \mathrm{~cm})$.
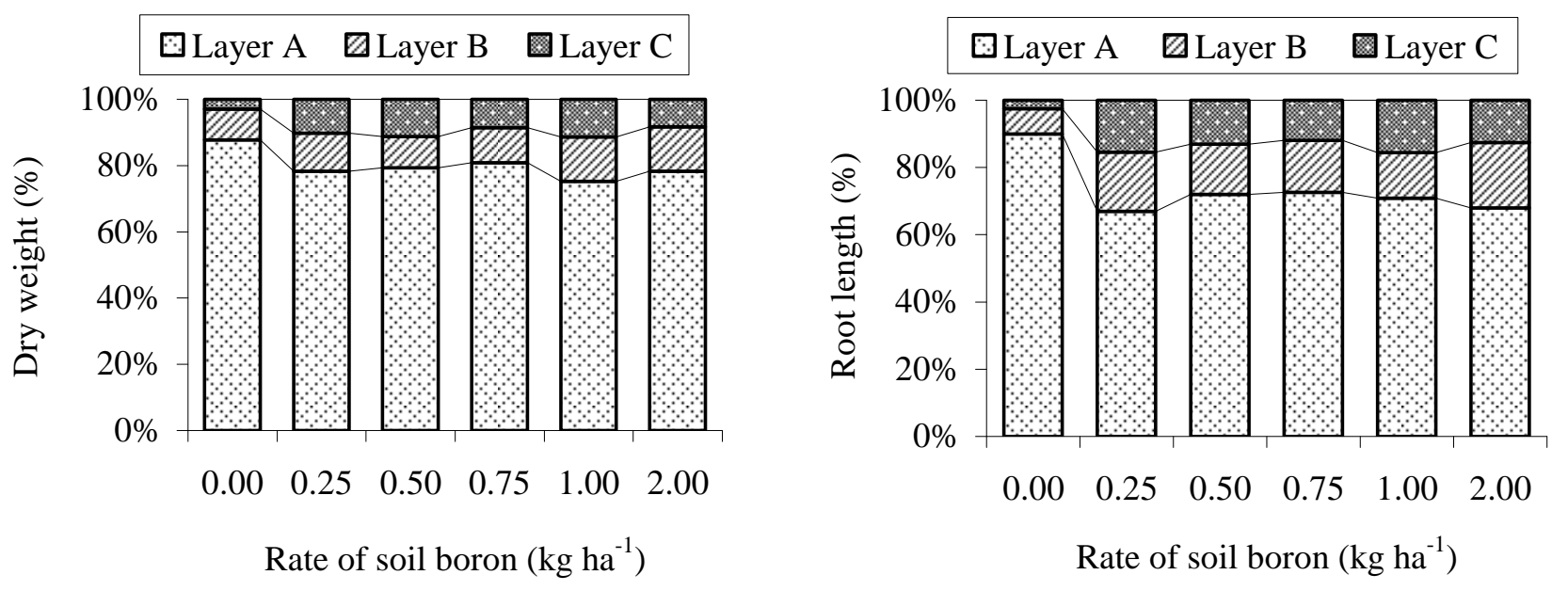

Figure 3 - Root dry weight and length as a percentage of each layer within each rate of boron applied to the profile with high Al in the subsoil. Layer A $(0-20 \mathrm{~cm}), \mathrm{B}(20-40 \mathrm{~cm})$ and $\mathrm{C}(40-60 \mathrm{~cm})$. 


\section{Root length}

Root length was significantly higher in the treatments with boron applied, compared to the control treatment (without B) only in layers B and $\mathrm{C}$ (Fig. 4). The A soil layer $(0-20 \mathrm{~cm})$ was limed and fertilized with $\mathrm{P}$ and $\mathrm{K}$, thus no $\mathrm{Al}$ was present in this layer. The lack of differences among the treatments showed that supplemental boron affected the root length only in the high Al layers. LeNoble et al. (1996b) reported that boron applied throughout a high Al profile promoted significant increases in the root length and dry weight at the $90-120 \mathrm{~cm}$ depth.
Increased root lengths of 7-29, 196-266, and $629-940 \%$ were observed for the respective first, second, and third layers where boron was applied compared to the control. This indicated that root length responded more to boron application than root dry weight, especially in the second and third layers $(20-60 \mathrm{~cm})$. Similarly, LeNoble et al. (1996b) noted higher increases in root length density compared to dry root weight with depth. This could be explained by an increase in the total number of lateral roots as was noted by Smith et al. (1993).

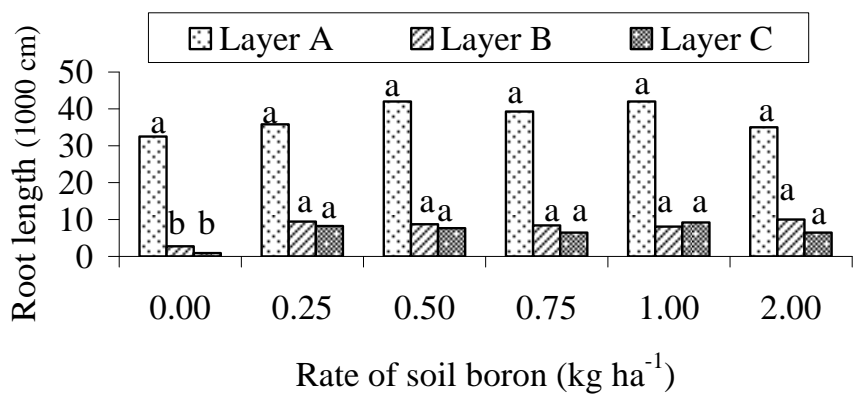

Figure 4 - Root length $(1000 \mathrm{~cm})$ as affected by boron fertilization in a profile with high $\mathrm{Al}$ in the subsoil. Means followed by the same letter within the each layer are not significantly different by Tukey's test at 5\%. Layer A $(0-20 \mathrm{~cm}), \mathrm{B}(20-40 \mathrm{~cm})$ and C $(40-60 \mathrm{~cm})$.

Root length by the depth showed the same trend as the root dry weight, with the highest concentration occurring in the upper $20 \mathrm{~cm}$. The average root length in layers $\mathrm{A}, \mathrm{B}$, and $\mathrm{C}$ was 37776, 7901, and $6486 \mathrm{~cm}$, respectively. Considering total root growth $(52163 \mathrm{~cm})$ independent of boron applied, layers A, B, and C constituted $72.4,15.2$ and $12.4 \%$ of the total, respectively. Fig. 3 shows the contribution of each layer within each rate of boron applied. As observed for the root dry matter, the boron application resulted in better root length distribution since only $10 \%$ of the root length was found in the $\mathrm{B}$ and $\mathrm{C}$ layer in the treatment without boron compared to $27-33 \%$ with boron.

Previous reports indicated that higher root growth in the sub-surface soil compared to plow layer, resulted in a more even root distribution in the soil profile when gypsum (Souza and Ritchey, 1986; Farina et al., 2000) and boron
(LeNoble et al., 1996b) were applied. This suggested that boron application could help the plant to resist drought and to use nutrients within the subsoil (Souza and Ritchey, 1986). This could explain the better seedling establishment, growth and survival of clover noted by Smith et al. (1993). The increase in root dry mass and length below the plow layer $(0-20 \mathrm{~cm})$ highlighted the importance of boron under high Al levels which could aid plants under stress conditions.

\section{Root ratio}

In the length measurement, the taproots were not considered, while with dry weight they were considered. Thus, apparently boron was more important for diameter than length. However, this was not observed in the present results. Root ratio did not show interaction between the soil layers and boron rates. Differences were 
observed only among the layers, and as expected, the values were higher in the layer A compared to the layers B and C.

\section{Soil}

As expected, the boron level increased linearly according to the rate applied to the soil for all the layers (Fig. 5). However, higher levels of boron were detected in the $\mathrm{C}$ layer compared to the others. This was probably due to the boron contribution from the upper soil layers since the sorption of boron to soil was weak (Pavan and

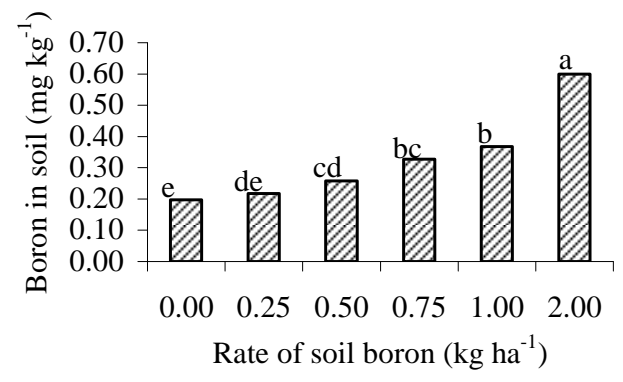

Correa, 1988), resulting high mobility, especially in the sandy soil (Gupta et al., 1985; Marschner, 1995). The amount of boron recovered from the $\mathrm{A}, \mathrm{B}$, and $\mathrm{C}$ layers was 72 , 76 , and $102 \%$ of the boron applied to the soil, respectively. The recovery was calculated using the angular coefficient from the regression between boron in the soil and the rate of boron applied to each layer. These results confirmed the high recovery of boron application from the fertilizer as well as the leaching effect (Gupta et al., 1985).

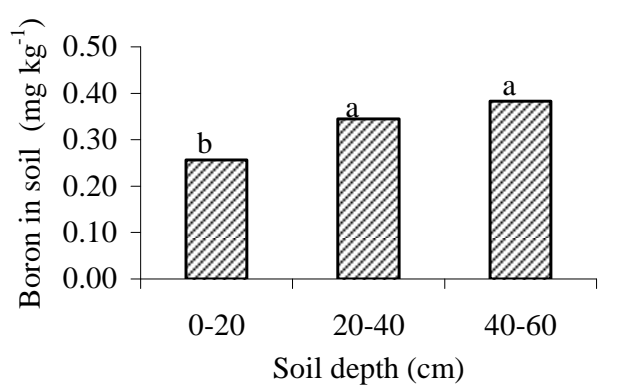

Figure 5 - Level of boron in soil $\left(\mathrm{mg} \mathrm{kg}^{-1}\right)$ within rate of boron applied $\left(\mathrm{kg} \mathrm{ha}^{-1}\right)$ by depth $(\mathrm{cm})$ as affected by boron fertilization in a profile with high $\mathrm{Al}$ in the subsoil. Means followed by the same letter within the each variable are not significantly different by Tukey's test at $5 \%$.

\section{RESUMO}

Estudos têm mostrado que o boro (B) afeta o crescimento das raízes em solo ácido reduzindo a toxidez do alumínio (Al). Para analisar a influência do boro no crescimento da parte aérea e raízes do Trifolium Vesiculosum (trevo vesiculoso) um perfil de solo ácido $(60 \mathrm{~cm}$ de profundidade com $67 \%$ de saturação de $\mathrm{Al}$ ) foi recriado em uma coluna (três camadas com 20 $\mathrm{cm}$ cada). Calcário e adubos $(\mathrm{P}$ e $\mathrm{K})$ foram incorporados na camada de $0-20 \mathrm{~cm}$. Os tratamentos consistiram de seis doses de boro sendo o ácido bórico incorporado em todo o perfil. A adubação com boro em solo com baixo $\mathrm{pH}$ e elevado $\mathrm{Al}$ aumentou o crescimento da parte aérea e raízes, no entanto, independente da dose aplicada. Boro pode inibir a toxidez de $\mathrm{Al}$, porém não observou-se efeito no comprimento de raízes sem a presença de Al no solo. Observou-se também um grande aumento no crescimento de raízes abaixo da camada arável $(0-20 \mathrm{~cm})$, fornecendo uma melhor distribuição de raízes no perfil do solo, o que pode ser importante para o crescimento da planta especialmente em condição de seca.

\section{REFERENCES}

Abreu, C. A. de; Abreu, M. F. de; Raij, B. van; Bataglia, O. C. and Andrade, J. C. (1994), Extraction of boron from soil by microwave heating for ICP-AES determination. Communications in Soil Science and Plant Analysis, 19/20, 3321-3333.

Box, G. E. P.; Hunter, W. G and Hunter, J. S. (1978), Statistics for experimenters: an introduction to design, data analysis, and model building. John Wiley, New York.

Castro, P. R. C.; Tavares, S.; Bertolotti, L.; Abe, R. G. and Yamada, T. (2003), Efeitos de fontes de boro no desenvolvimento radicular do girassol (Heliantus annus) em rizotrons. Rev. de Agricultura, 78, 181-192. 
Comissão de Fertilidade do Solo - RS/SC. (1994), Recomendações de adubação e calagem para os estados do Rio Grande do Sul e de Santa Catarina. $3^{\mathrm{a}}$ ed. SBCS-Núcleo Regional Sul, Passo Fundo.

Dunlop, J. and Hart, A. L. (1987), Mineral nutrition. In: Baker, M. J. and Willians, W. M. White clover. Cambrian News, United Kindgom.

EMBRAPA - Empresa Brasileira de Pesquisa Agropecuária. (1997), Manual de métodos de análise de solo. $2^{\mathrm{a}}$ ed. EMBRAPA, Rio de Janeiro.

Farina, M. P. W.; Channon, P. and Thibaud, G. R. (2000), A comparison of strategies for ameliorating subsoil acidity: I. Long-term growth effects. Soil Sci. Soc. Am. J. 64, 646-651.

Grassi Filho, H.; Dechen, A. R.; Torquato, E. M. and Santos, C.H. dos. Fenologics characteristics of the 'Siciliano' lemon tree on two rootstocks influenced by liming and boron addition. Brazilian Archives of Biology and Technology. 47, 677-684.

Gupta, U. C.; Jame, Y. W.; Campbell, C. A.; Leyshon, A. J. and Nicholaichuk, W. (1985), Boron toxicity and deficiency: a review. Canadian Journal of Soil Science, 65, 381-409.

Haby, V. A.; Smith C. R.; Pratt J. N.; Brown J. R. and. Sanders J. L. (1993), Boron improves clover production. Better Crops with Plant Food, 77, 2021.

Hildebrand, C. (1977), Manual de análises químicas de solos e plantas. Universidade Federal do Paraná, Curitiba.

Hoveland, C. S. and Evans, G. W. (1995), Arrowleaf, crimson, and other annual clovers. In: Barnes, R. F.; Miller, D. A. and Nelson, C. F. Forages: an introduction to grassland agriculture. Iowa State University Press, Ames.

IAC - Instituto Agronômico de Campinas. (1996), Recomendação de adubação e de calagem para o estado de São Paulo, $2^{\mathrm{a}}$ ed., Instituto Agronômico and Fundação IAC, Campinas, Boletim técnico 100.

Lenoble, M. E.; Blevins, D. G. and Miles, R. J. (1996b), Prevention of aluminium toxicity with supplemental boron. II. Stimulation of root growth in an acidic, high-aluminium subsoil. Plant, Cell and Environmen, $t$ 19, 1143-1148.
Lenoble, M. E.; Blevins, D. G.; Sharp, R. E. and Cumbe, B. G. (1996a), Prevention of aluminium toxicity with supplemental boron. I. Maintenance of root elongation and cellular structure. Plant, Cell and Environment, 19, 1132-1142.

Luchese, E. B.; Lenzi, E. and Favero, L. O. B. (1994). Levantamento preliminar dos teores de boro nos solos do Paraná - BR. Arq. Biol. Tecnol., 37, 345-351.

Lukaszewski, K. M. and Blevins, D. (1996), Root growth inhibition in boron-deficient or aluminumstressed squash may be a result of impaired ascorbate metabolism. Plant Physiol., 112, 11351140 .

Marschner, H. (1995), Mineral nutrition of higher plants. $2^{\text {nd }}$ ed. Academic Press, San Diego, California.

Pavan, M. A. and Correa, A. E. (1988), Reações de equilíbrio solo-boro. Pesq. Agrop. Bras., 23, 26126.

Pavan, M. A.; Bloch, M. de F.; Zempulski, H. da C.; Miyazawa, M. and Zocoler D. C. (1992), Manual de análise química de solo e controle de qualidade. IAPAR, Londrina, Circular 76.

Shenk, M. K. and Barber, S. A. (1979), Root characteristics of corn genotypes as related to $\mathrm{P}$ uptake. Agronomy Journal. 71, 921-924.

Smith, G. R.; Haby, V .A.; Gilbert, C. L. and Pemberton, I. J. (1993), Effects of boron on seedling establishment of annual Legumes. Better Crops with Plant Food, 77, 18-19.

Souza, D. M. G. and Ritchey, K. D. (1986), Correção de acidez sub-superficial: uso de gesso no solo de Cerrado. In. Dechen, A. R. (Cood.). Simpósio Avançado de Química e Fertilidade do Solo. Fundação Cargill, Piracicaba, p. 91-113.

Tennant D. (1975), A test of a modified line intersect method of estimating root length. The Journal of Ecology. 63, 995-1001.

Tisdale, S. L.; Nelson, W. L.; Beaton, J. D and Havlin J. L. (1993), Soil fertility and fertilizers. $5^{\text {th }}$ ed. Prentice Hall, New York.

Received: November 01, 2005; Revised: August 04, 2006; Accepted: March 12, 2007. 